\title{
Abundant and rare spiders on tree trunks in German forests (Arachnida, Araneae)
}

\section{Theo Blick}

doi: $10.5431 /$ aramit4002

\begin{abstract}
The spider fauna active on the bark of trees in forests on eight sites in different regions in Germany was investigated. Trunk eclectors at about 2-4 meters height on living trees were used in different regions of Germany (SW Bavaria, Hesse, Brandenburg) between 1990 and 2003. In Hesse eclectors were also used on dead beech trees (standing and lying). In this study data, mainly from beech (Fagus sylvatica) and spruce (Picea abies), from May to October are compared - whole year samples (including winter) are only available from Hesse. A total of 334 spider species were recorded with these bark traps, i.e. about one third of the spider species known from Germany. On average, each of the eight regions yielded 140.5 ( \pm 26.2$)$ species, each single tree $40.5( \pm 12.2)$ species and 502 ( \pm 452) adult spiders per season (i.e. May to Oct.). The 20 most abundant species are listed and characterised in detail. Six of the 20 species were not known to be abundant on bark, three prefer conifers and three beech/broadleaf. Even in winter (December-March) there was a remarkably high activity on the trunks. However, only a few species occur exclusively or mainly in winter. Finally, the rarity of some bark spider species is discussed and details (all known records in Germany, phenology) of four of them are presented (Clubiona leucaspis, Gongylidiellum edentatum, Kratochviliella bicapitata, Oreonetides quadridentatus). The diversity and importance of the spider fauna on bark in Central Europe is still underestimated.
\end{abstract}

Key words: bark, common species, distribution, eclectors, Germany, rare species

The spider fauna of tree trunks in Germany and Central Europe is much less well known than the epigeal fauna active on the forest floor. Only the fauna of the tree crowns is more poorly known (SIMON 1995, GOSSNER 2004, RÖDER et al. 2010). Furthermore, the epigeal spider fauna of common forest types - at least in Central Europe - is significantly less intensively investigated than that of the epigeal fauna of special habitats, such as those that are extremely dry or wet (HÄNGGI et al. 1995). I estimate that this disproportion is much higher, if one compares the epigeal spider fauna in forests with the tree trunk spider fauna. In Central European forests knowledge about the tree trunk fauna reaches an estimated maximum level of $5 \%$ compared with the epigeal fauna.

Before the research in Strict Forest Reserves in Hesse started, estimates of the species richness of animals (biodiversity) in a beech forest were 1500-2000 species (all animals) (ELLENBERG et al. 1986). Now we know that there are closer to 5000-6000 (DOROW et al. 2004, 2010). In each of the four Strict Forest Reserves investigated until now 162 to 202 spider species were recorded (BLICK 2009).

\footnotetext{
Theo BLICK, Senckenberg Forschungsinstitut und Naturmuseum, Projekt Hessische Naturwaldreservate, Senckenberganlage 25,60325 Frankfurt am Main, Germany, E-Mail:theo.blick@senckenberg.de
}

As the complete spider coenoses and species lists were already published (see below) or will be published elsewhere, the focus here is on the following topics: (a) totals of species and abundances, (b) the 20 most abundant spider species, (c) winter activity, and (d) notes on rarely or very rarely recorded species.

\section{Methods}

Trunk eclectors (Fig. 1, method after BEHRE 1989, see also BRAUN 1992, Dorow et al. 1992, ENGEL 1999) at heights from 2 to 4 meters on living trees were used in different regions of Germany (SW Bavaria, Hesse, Brandenburg) (Fig. 2). In Strict Forest Reserves in Hesse eclectors were also used on dead beech trees (on standing trees and with an adapted type of trap, also on lying trees) (DoROW et al. 1992).

The traps were operated during different time periods in the different regions and projects. The trapping periods from May to October were available for comparison from nearly all sites (except Brandenburg). Hesse (Strict Forest Reserves) was the only area where data were available for the whole year, i.e. two entire years including two winters.

Most data sets are from beech - Fagus sylvatica and spruce - Picea abies; see details below. 

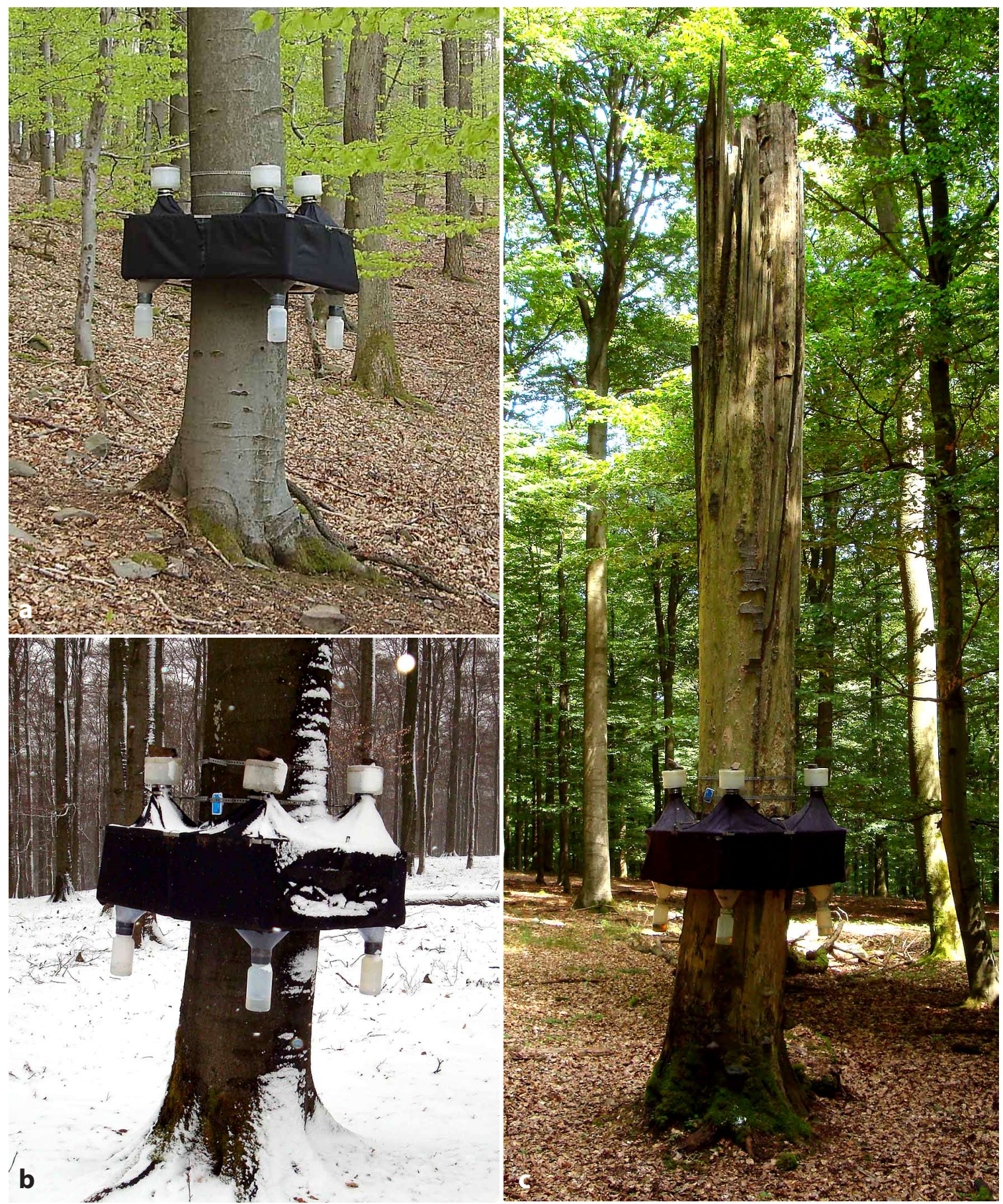

b

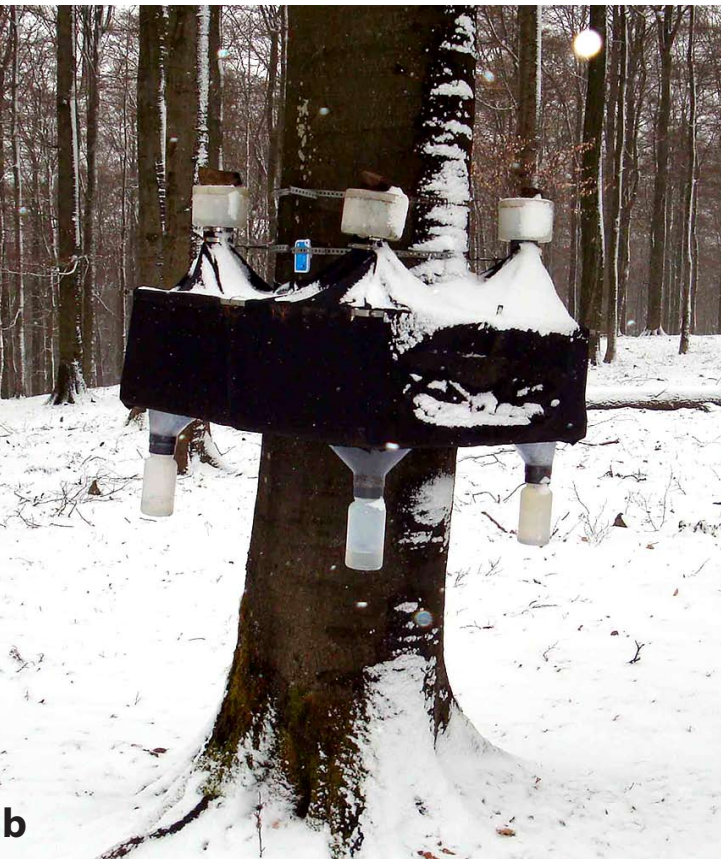

Figure 1:Trunk eclectors on standing beech trees in northern Hesse, Germany, a - spring, b - winter, c - dead tree

\section{Sites}

The data included in this study came from different sites in Germany (Fig. 2):

- Three pairs of pine forests, also part mixed with beech and oak, in Brandenburg (no. 1 in Fig. 2, two forests in the north, one in the south) (unpubl. data from 2000 and 2001, June to September, leg. T. Taeger \& U. Schulz, det. TB). In each of the six forests six trunk eclectors were installed on Scots pine - Pinus sylvestris. A total of 36 trees were investigated. 
- In four Strict Forest Reserves and their reference areas, where forestry is continued, in Hesse (nos. 2-5 in Fig. 2) trunk eclectors were installed on two living and two dead standing beech trees during two whole years (MALTEN 1999, 2001, MALTEN \& BLICK 2007, BLICK 2009). Additionally at least two eclectors on lying dead beech trees were installed in each reserve. In total 30 standing and 13 lying dead trees were investigated.

- Mixed forest ('Stadtwald'), between the urban area of Frankfurt am Main and its airport. 12 trees (alder - Alnus glutinosa, ash - Fraxinus excelsior, birch - Betula pendula, two beeches, douglas fir - Pseudotsuga menziesii, elm - Ulmus laevis, Scots pine, two common oaks - Quercus robur, sessile oak - Quercus petraea) were investigated with trunk eclectors in 2000 (beginning of February/mid-March to beginning of November) (MALTEN et al. 2003, det. in part by TB) (no. 6 in Fig. 2).

- Forest near Biburg, east of Augsburg, Bavaria (no. 7 in Fig. 2); eight young beeches, four young spruces (20-40 y), two older beeches, two older spruces (about $100 \mathrm{y}$ ); beginning of April to end of October 1996 (ENGEL 1999, 2001, det. mainly by TB).

- Forests near Krumbach and Ottobeuren, Bavaria (no. 8 in Fig. 2); 16 beeches, eight douglas firs, eight common oaks, two northern red oaks - Quercus rubra, two silver firs - Abies alba, 22 spruces (unpubl. data from 1999 to 2003, April to October, with exceptions of 1999 (beginning in June) and of 2000 (until November), leg. K. Engel \& M. Gossner, det. TB).

\section{Results}

\section{Totals}

In total 334 spider species, i.e. one third of the spider fauna of Germany, were recorded with 98328 adult spiders. In the 8 different regions between 106 and 177 spider species were recorded, with an average of 140.5 species $( \pm 26.2$ standard deviation) (Tab. 1).
Table 1:Totals of the spiders in the trunk eclectors from the 8 sites

\begin{tabular}{c|c|r} 
region no. & species & \multicolumn{1}{|c}{ adults } \\
\hline 1 & 123 & 6174 \\
2 & 116 & 7796 \\
3 & 130 & 10375 \\
4 & 149 & 8399 \\
5 & 149 & 6685 \\
6 & 174 & 9283 \\
7 & 106 & 4904 \\
8 & 177 & 44712
\end{tabular}

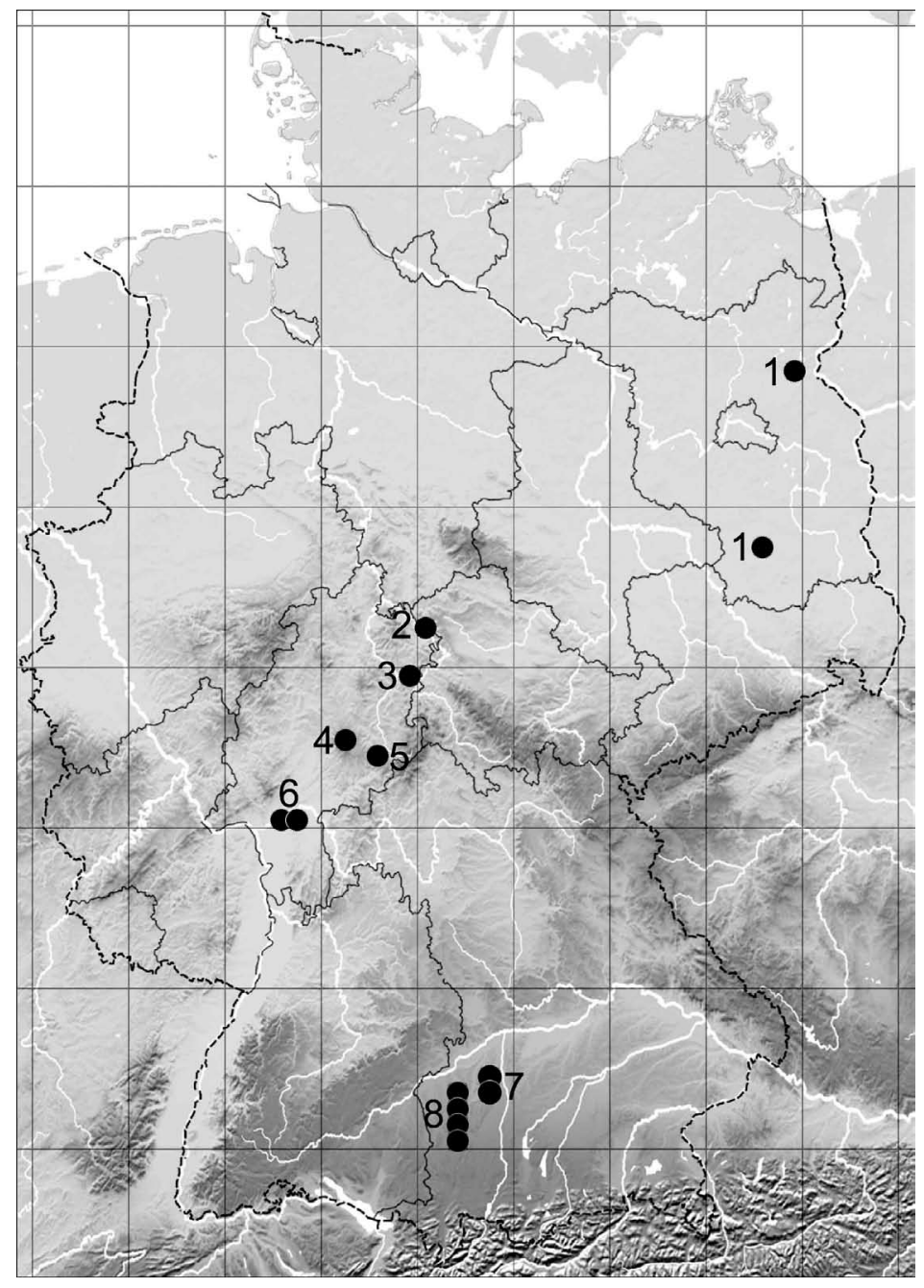

Figure 2: Sites with trunk eclectors in Germany, included into this study 1: forests in Brandenburg (Blick \& Schultz unpubl.); 2-5: Strict Forest Reserves in Hesse (2: Hohestein, MALTEN \& BLICK 2007; 3: Goldbachs- und Ziebachsrück, BLICK 2009; 4: Niddahänge östlich Rudingshain, MALTEN 1999; 5: Schönbuche, MALTEN 2001); 6: Stadtwald, Frankfurt am Main, Hesse (MALTEN et al. 2003); 7: forest near Biburg, east of Augsburg, Bavaria (ENGEL 1999, 2001); 8: forests near Krumbach and Ottobeuren, Bavaria (Blick et al. unpubl.); see text. 
Between 21 and 88 spider species were recorded per tree and season (i.e. May-Oct. - based on 115 living trees/season and a total of 298 species), with an average $(\varnothing)$ of 40.5 species $( \pm 12.2)$. Altogether 122 to 2696 adult spiders per tree and season were trapped, $\varnothing 502$ ( \pm 452$)$.

\section{Twenty most abundant spider species}

In Tab. 2 the 20 most abundant spider species are sorted in descending abundance. Regional distribution (focus or exclusivity - if nothing is noted the species was recorded in every one of the 8 regions), the tendency to occur on broadleaves/conifers and other notes are added.

To summarise:

- 8 of the 20 species (40\%) were linyphiids, 10 families were present

- only 2 species belong to the same genus (Xysticus)

- 6 species are not known yet as abundant bark species (compare e.g. WUNDERLICH 1982)

- 14 species are abundant in (nearly) all regions investigated, 6 species have a more regional distribution

- 3 species prefer conifers, 3 species prefer beeches/ broadleaves [3 other species were only or mainly trapped in regions, where all/most of the traps were on beech/broadleaf]

- these 20 most abundant species make up 65281 adults, i.e. $66.4 \%$ of the adult spiders from the trunks

\section{Most abundant spider species active in winter}

A similar analysis was made for the winter active species (trapping months December to March, including long winter trapping periods in the regions which ended at the end of April or even at the beginning of May in some years). This means that mainly data of the regions 2-5 (see Fig. 2) and only some additional data of region 6 could be analysed. All these data came from the federal state Hesse. A total of 140 species, 7356 adults and 15714 juveniles (9833 determinable to species level) were recorded during the winter periods.

Even in winter, numerous spiders were found in the trunk eclectors. Only two representatives of the commonly known winter-active spiders (e.g. the linyphiid genera Centromerus, Macrargus and Walckenaeria; the dictynid Cicurina) are on this list (Tab. 3). The majority of the species are also included in Tab. 2. Compared to the forest floor, fewer species on bark were exclusively active in winter. Only Cicurina cicur and Thyreosthenius parasiticus can strictly be placed in the latter category, but at some sites also Monocephalus castaneipes. The 9 species with more than 100 adult individuals comprise 5930 (81\%) of the adult spiders from the trunks in the winter - a much less balanced pattern than in the summer (see above).

\section{Rare spider species}

There are several 'types' of rare spider species: (a) widely distributed but rare, (b) at or near the border of their distribution area, (c) with restricted distribution areas (Central European endemics?). Examples of species for these types are listed as follows: species name (family), adults recorded (ind.), and distribution area. PlatNicK (2009), STAUDT (2009) and MiKHAILOV (1997) were used as main sources for the total distribution of each species.

\section{(a) widely distributed but rare}

Araneus saevus (L. Koch, 1872) (Araneidae), 2 ind., Holarctic

Carrhotus xanthogramma (Latreille, 1819) (Salticidae), 59 ind., Palaearctic

Dendryphantes hastatus (Clerck, 1757) (Salticidae), 32 ind., Palaearctic

Dipoena torva (Thorell, 1875) (Theridiidae), 120 ind., Europe to W Siberia

Mastigusa arietina (Thorell, 1871) (Dictynidae), 3 ind., Europe

Philodromus buchari Kubcová, 2004 (= P. longipalpis auct. in Central Europe) (Philodromidae), 19 ind., Europe and Turkey

Stroemiellus stroemi (Thorell, 1870) (Araneidae), 1 ind., Palaearctic

Interestingly there are no records of the very rare tree-living species Philodromus poecilus (Thorell, 1872) (Philodromidae), Palaearctic (see MUSTER 2009) and Xysticus albomaculatus Kulczyński, 1891 (Thomisidae), Germany to Romania, probably Russia (see JANTSCHER 2001).

(b) at or near the border of their distribution

Cinetata gradata (Simon, 1881) (Linyphiidae), 76 ind., central and southern Europe, mainly in mountainous areas, its northern border of distribution is situated in Germany.

Clubiona leucaspis Simon, 1932 (Clubionidae) (Figs. 3a, 4a), 583 ind., southern and central Europe, i.e. the northern border is located in Germany, in Germany only in the north-eastern and south-western 
Table 2: The twenty most abundant bark spider species (see text)

\begin{tabular}{|c|c|c|c|c|}
\hline $\begin{array}{c}\text { species (family) } \\
(\text { bold }=\text { not well known as bark species })\end{array}$ & \begin{tabular}{c|} 
adults \\
recorded
\end{tabular} & $\begin{array}{l}\text { regional focus or } \\
\text { exclusivity } \\
\text { (nos. see fig. 2) }\end{array}$ & $\begin{array}{l}\text { tendency to/focus } \\
\text { on tree types }\end{array}$ & notes \\
\hline $\begin{array}{l}\text { Hahnia pusilla C.L. Koch, } 1841 \\
\text { (Hahniidae) }\end{array}$ & 15308 & $\begin{array}{c}7 \& 8, \text { single } \\
\text { specimens in } 3 \\
\& 5\end{array}$ & & $\begin{array}{l}\text { only } 58 \text { males, females } \\
\text { also on the forest floor, } \\
\text { males mainly on the } \\
\text { floor }\end{array}$ \\
\hline $\begin{array}{l}\text { Amaurobius fenestralis (Ström, 1768) } \\
\text { (Amaurobiidae) }\end{array}$ & 8780 & & & $\begin{array}{l}\text { also juveniles were } \\
\text { determined (in total } \\
\text { 16579), also on the } \\
\text { forest floor }\end{array}$ \\
\hline $\begin{array}{l}\text { Pelecopsis elongata (Wider, 1834) } \\
\text { (Linyphiidae) }\end{array}$ & 5186 & $7 \& 8$ & & $\begin{array}{l}\text { rarely also found on the } \\
\text { forest floor or in scree } \\
\text { and talus habitats }\end{array}$ \\
\hline $\begin{array}{l}\text { Drapetisca socialis (Sundevall, 1833) } \\
\text { (Linyphiidae) }\end{array}$ & 5087 & & $\begin{array}{l}\text { slight preference for } \\
\text { beech }\end{array}$ & also 3145 juv. recorded \\
\hline $\begin{array}{l}\text { Xysticus audax (Schrank, 1803) } \\
\text { (Thomisidae) }\end{array}$ & 4106 & & $\begin{array}{l}\text { preference for } \\
\text { conifers }\end{array}$ & \\
\hline $\begin{array}{l}\text { Walckenaeria cuspidata Blackwall, } 1833 \\
\text { (Linyphiidae) }\end{array}$ & 3076 & $2 \& 3$, few in 4 & $\begin{array}{l}\text { [2-4: only traps on } \\
\text { beech] }\end{array}$ & also on the forest floor \\
\hline $\begin{array}{l}\text { Enoplognatha ovata (Clerck, 1757) } \\
\text { (Theridiidae) }\end{array}$ & 2691 & & & \\
\hline $\begin{array}{l}\text { Lathys humilis (Blackwall, 1855) } \\
\text { (Dictynidae) }\end{array}$ & 2630 & $\begin{array}{c}\text { mainly } 8, \\
\text { not } 3\end{array}$ & $\begin{array}{l}\text { slight preference for } \\
\text { conifers }\end{array}$ & \\
\hline $\begin{array}{l}\text { Moebelia penicillata (Westring, 1851) } \\
\text { (Linyphiidae) }\end{array}$ & 2300 & & & \\
\hline $\begin{array}{l}\text { Neon reticulatus (Blackwall, 1853) } \\
\quad \text { (Salticidae) }\end{array}$ & 1897 & majority in 8 & $\begin{array}{l}\text { slight preference for } \\
\text { conifers }\end{array}$ & $\begin{array}{l}\text { only } 17 \text { males, both } \\
\text { sexes mainly on the } \\
\text { forest floor }\end{array}$ \\
\hline $\begin{array}{l}\text { Cryphoeca silvicola (C.L. Koch, 1834) } \\
\text { (Hahniidae) }\end{array}$ & 1837 & $\begin{array}{l}\text { mainly } 8 \\
\text { not } 1 \& 6\end{array}$ & & also on the forest floor \\
\hline $\begin{array}{l}\text { Entelecara erythropus (Westring, 1851) } \\
\text { (Linyphiidae) }\end{array}$ & 1574 & 2-6 (Hesse) & $\begin{array}{l}{[2-6: \text { most traps on }} \\
\text { beeches/broadleaf }]\end{array}$ & also on the forest floor \\
\hline $\begin{array}{l}\text { Coelotes terrestris (Wider, 1834) } \\
\text { (Amaurobiidae) }\end{array}$ & 1525 & not 1 & preference for beech & $\begin{array}{l}\text { mainly on the forest } \\
\text { floor }\end{array}$ \\
\hline $\begin{array}{l}\text { Xysticus lanio (Schrank, 1803) } \\
\text { (Thomisidae) }\end{array}$ & 1504 & & $\begin{array}{l}\text { preference for } \\
\text { broadleaf }\end{array}$ & \\
\hline $\begin{array}{l}\text { Lepthyphantes minutus (Blackwall, 1833) } \\
\text { (Linyphiidae) }\end{array}$ & 1491 & & & \\
\hline $\begin{array}{l}\text { Philodromus collinus C.L. Koch, } 1835 \\
\text { (Philodromidae) }\end{array}$ & 1381 & & & rarer on the forest floor \\
\hline $\begin{array}{l}\text { Meioneta innotabilis (O. P.-Cambridge, 1863) } \\
\text { (Linyphiidae) }\end{array}$ & 1358 & $\begin{array}{c}\text { not } 3 \\
\text { rare in } 2,4,5,7\end{array}$ & & \\
\hline $\begin{array}{l}\text { Diplocephalus cristatus (Blackwall, 1833) } \\
\text { (Linyphiidae) }\end{array}$ & 1288 & $\begin{array}{c}2 \& 3 \\
\text { singleton in } 4\end{array}$ & $\begin{array}{l}{[2-4: \text { only traps on }} \\
\text { beech] }\end{array}$ & $\begin{array}{l}\text { mainly on the forest } \\
\text { floor, also in open land } \\
\text { habitats }\end{array}$ \\
\hline $\begin{array}{l}\text { Harpactea hombergi (Scopoli, 1763) } \\
\text { (Dysderidae) }\end{array}$ & 1170 & $\begin{array}{l}\text { mainly 6, } \\
\text { few in } 3 \& 8\end{array}$ & & also on rocks and walls \\
\hline $\begin{array}{l}\text { Anyphaena accentuata (Walckenaer, 1802) } \\
\text { (Anyphaenidae) }\end{array}$ & 1092 & not 4 & & $\begin{array}{l}\text { also juveniles can be } \\
\text { determined (in total } \\
\text { 10322), rare on the } \\
\text { forest floor }\end{array}$ \\
\hline
\end{tabular}



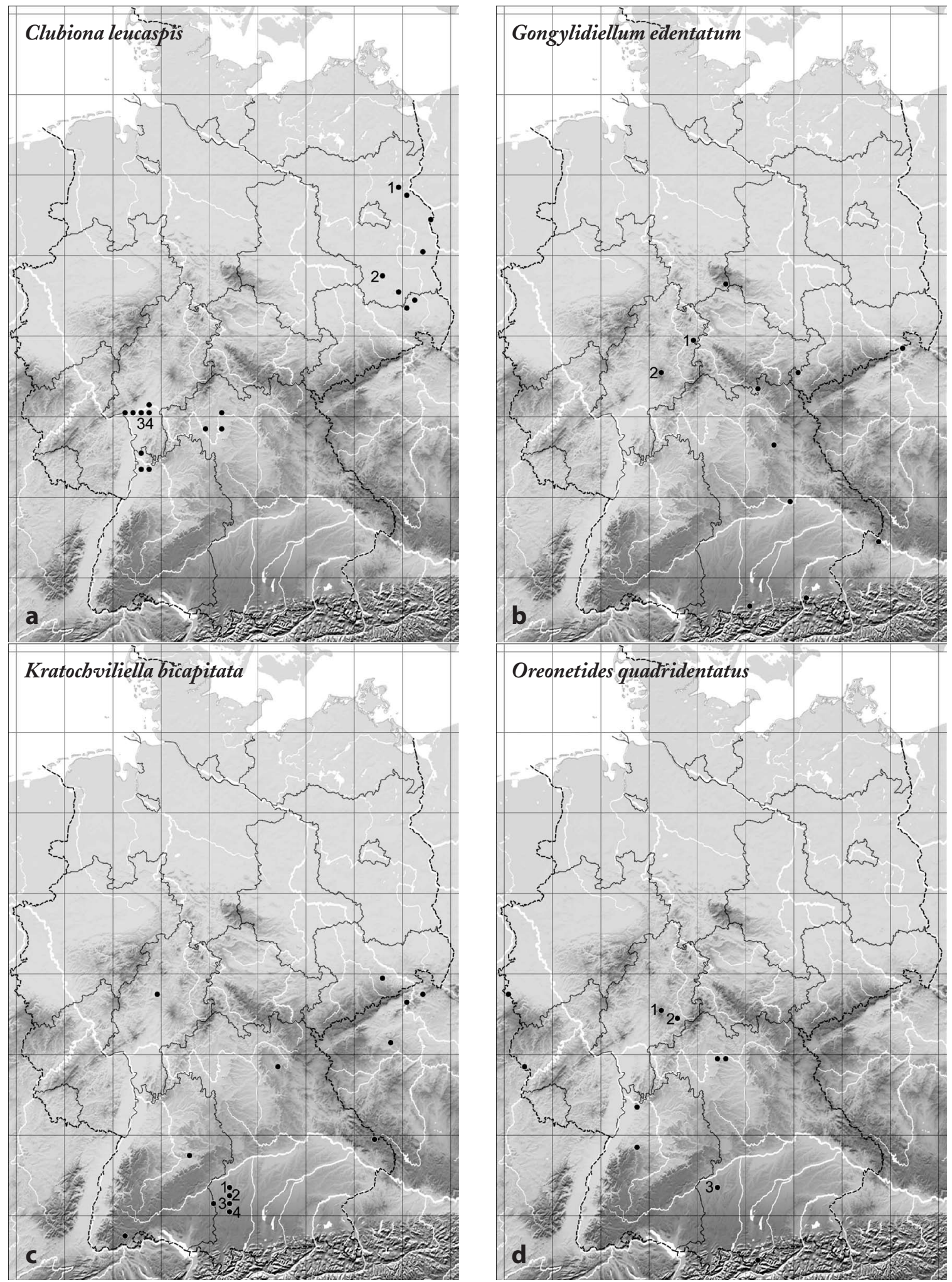

Figure 3: Distribution maps for Germany of four of the rare spider species (after STAUDT 2009); a Clubiona leucaspis, 1 \& 2: Blick \& Schultz (unpubl.); 3 \& 4: MALTEN et al. (2003); b Gongylidiellum edentatum, 1: BLICK (2009), 2: MALTEN (1999); c Kratochviliella bicapitata, 1-4: Blick et al. (unpubl.); d Oreonetides quadridentatus, 1: MALTEN (1999), 2: MALTEN (2001), 3: Blick et al. (unpubl.) 
Table 3: Most abundant winter active spider species (>100 specimens)

\begin{tabular}{|c|c|c|c|c|}
\hline $\begin{array}{c}\text { species } \\
\text { (family - only when the species is not } \\
\text { present in Tab. 2) }\end{array}$ & ad./juv. & $\begin{array}{l}\text { regional focus or } \\
\text { exclusivity } \\
\text { (nos. see fig. 2) }\end{array}$ & $\begin{array}{l}\text { winter activity } \\
\quad(\text { if }>50 \%)\end{array}$ & $\begin{array}{l}\text { notes } \\
\text { (additional } \\
\text { to Tab. 2) }\end{array}$ \\
\hline \multicolumn{5}{|c|}{ adults } \\
\hline Amaurobius fenestralis (Ström, 1768) & 2391 & & & $87 \%$ males \\
\hline Walckenaeria cuspidata Blackwall, 1833 & 1685 & $2 \& 3$, few in 4 & $55 \%$ & \\
\hline $\begin{array}{l}\text { Monocephalus castaneipes (Simon, 1884) } \\
\text { (Linyphiidae) }\end{array}$ & 839 & only $4 \& 5$ & $81 \%$ & also on the forest floor \\
\hline $\begin{array}{l}\text { Cicurina cicur (Fabricius, 1793) } \\
\text { (Dictynidae) }\end{array}$ & 292 & not 6 & $77 \%$ & also on the forest floor \\
\hline Moebelia penicillata (Westring, 1851) & 156 & & & \\
\hline $\begin{array}{l}\text { Thyreosthenius parasiticus (Westring, 1851) } \\
\text { (Linyphiidae) }\end{array}$ & 156 & not 5 & $74 \%$ & rarely on the forest floor \\
\hline Diplocephalus cristatus (Blackwall, 1833) & 147 & only $2 \& 3$ & & \\
\hline Drapetisca socialis (Sundevall, 1833) & 140 & & & \\
\hline $\begin{array}{l}\text { Labulla thoracica (Wider, 1834) } \\
\text { (Linyphiidae) }\end{array}$ & 124 & not 6 & & also on the forest floor \\
\hline \multicolumn{5}{|c|}{ juveniles } \\
\hline Anyphaena accentuata (Walckenaer, 1802) & 4555 & not 4 & $59 \%$ & \\
\hline Amaurobius fenestralis (Ström, 1768) & 3105 & & & \\
\hline $\begin{array}{l}\text { Diaea dorsata (Fabricius, 1777) } \\
\text { (Thomisidae) }\end{array}$ & 905 & & & \\
\hline $\begin{array}{l}\text { Clubiona leucaspis Simon, } 1932 \\
\text { (Clubionidae) }\end{array}$ & 557 & only 6 & & $\begin{array}{l}\text { see section 'rare spider } \\
\text { species' }\end{array}$ \\
\hline Cryphoeca silvicola (C.L. Koch, 1834) & 199 & not 6 & $75 \%$ & \\
\hline Lathys humilis (Blackwall, 1855) & 111 & not $2 \& 4$ & $84 \%$ & \\
\hline
\end{tabular}

regions with the highest average temperatures, only lowlands. First record for Germany by MALTEN (1994). Note: some records of C. genervensis L. Koch, 1866 on trees might really represent further records of C. leucaspis. For the typical colouration see: http://spiderling.de/arages/Fotogalerie/species_fg.php?name=Clubiona\%20leucaspis (STAUDT 2009).

Clubiona marmorata L. Koch, 1866 (Clubionidae), 64 ind., central to south-eastern Europe, its northwestern border is situated in Germany.

Monocephalus castaneipes (Simon, 1884) (Linyphiidae), 1035 ind., central to northern, western and south-western Europe, eastern border in Germany.

Theridion boesenbergi Strand, 1904 (Theridiidae), 105 ind., central and eastern Europe, without northern parts, mainly in mountainous areas, northern border in Germany. (c) with restricted distributions; central European 'endemics' (all belong to the Linyphiidae)

Gongylidiellum edentatum Miller, 1951 (Figs. 3b, 4b, 10 ind., central Europe (Germany, Czech Rep., Austria), N Italy, SE France, most numerous record (31 specimens) is from a rotting beech stump in Hesse (BLICK 2009), see also below.

Kratochviliella bicapitata Miller, 1938, 878 ind., central Europe (Germany, Austria, Czech Rep., Slovakia, Poland), Bulgaria; besides the specimens presented here there is just one other record of a larger number of individuals in Poland (CZAJKA \& BEDNARZ 1972: "only on the northern surface of the tree trunks.... We estimated that the whole population consisted of some 6000-7000 specimens at that time"), see also below.

Oreonetides quadridentatus (Wunderlich, 1972), 82 ind., central Europe (Germany, Austria, Luxembourg) and one record with four specimens from the French Pyrenees (Bosmans et al. 1986); the 
record presented here probably refers to the greatest number of individuals found until now.

Pseudocarorita thaleri (Saaristo, 1971), 64 ind., central Europe (Germany, Czech Rep., Austria, Switzerland, Belgium).

More details on four of the rare species mentioned above are presented in Figs. 3 and 4, because very little information has previously been published on them. The phenologies of these four species are presented in Fig. 4. The trapping periods are assigned to the month to which the majority of the days of each trapping period belonged; this may not be the month in which the trap was changed or emptied. For Gongylidiellum edentatum and Kratochviliella bicapitata supplementary data are included, i.e. unpublished data from other sites, or from the sites mentioned in this paper but caught with methods other than trunk eclectors.

\section{Discussion}

TOFT (1976) caught 3195 spiders from the end of April to mid-December with 'arboreal photoeclectors' (method after NIELSEN 1974) but gave no species number for the individual methods used (total species number $=147)$. ALBERT $(1982)$ was the first to publish detailed data from trunk eclectors (method
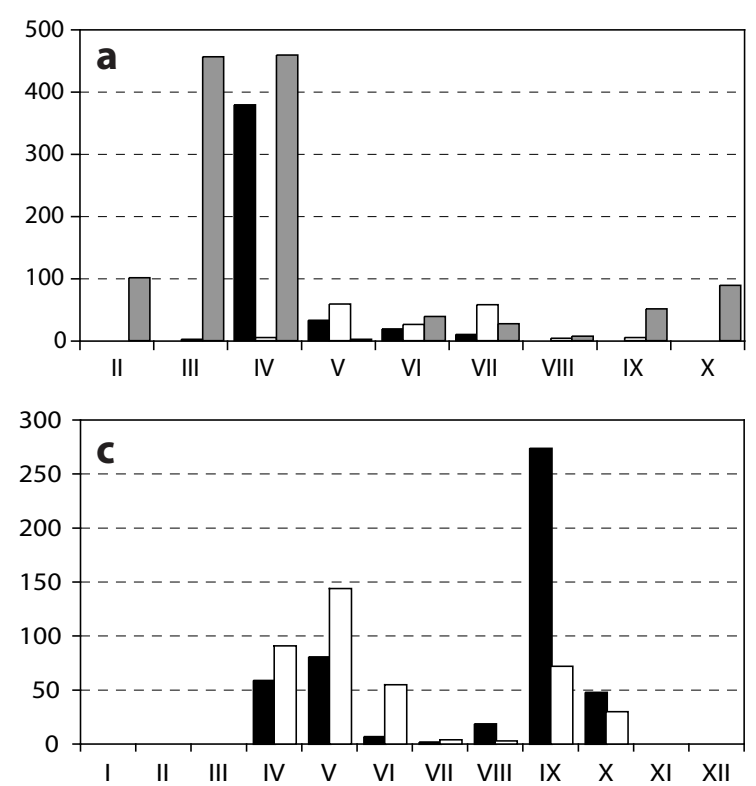

after FUNKE 1971, i.e. without trapping bottles at the bottom; by contrast the type after BEHRE 1989 uses bottles at the bottom, Fig. 1). The eclectors were installed on beeches and spruces and were operated from March/April to November/December in 1969 and 1971 . He gives no total species number for the trunk eclectors, but for the four investigated types: spruce old (52 species, 4025 adults), spruce young (39 sp., 972 ad.), beech old (67 sp., 1525 ad.), beech young (33 sp., 199 ad.). PLATEN (1985, also with the eclector type of FUNKE 1971) recorded 74 species over two whole years, 69 on beech and 37 on spruce.

Some other examples: BRAUN (1992), who already used the eclector type of BEHRE 1989, caught 108 spider species (3709 adults) on trunks of Scots pine at 3 different heights above the forest floor (1, 4 and 8 meters) from May to Oct. SIMON (1995), also trapped on Scots pine and at different heights (1.5, 5, 10 and 13 meters - species numbers $71,59,48,35$, i.e. lower numbers at increasing height), over 3 whole years collecting a total of 103 species (including traps on branches in the crown). GOERTZ (1998) examined 10 trees (5 crack willows - Salix fragilis, 2 almond willows - Salix triandra, 3 black poplars - Populus aff. nigra) from mid-December to end of June and caught a total of 100 species and 20167 determinable
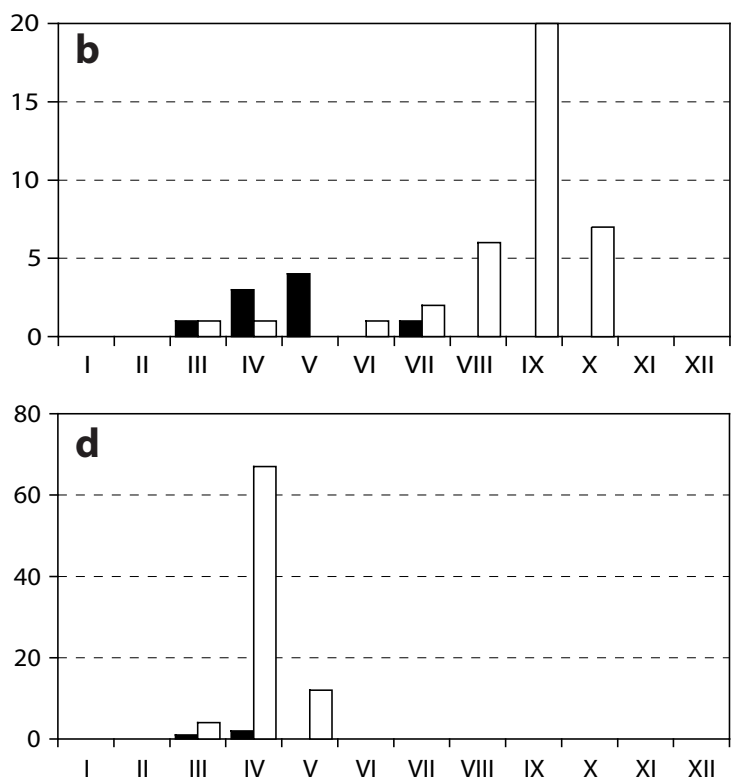

Figure 4: Phenology of (a) Clubiona leucaspis, (b) Gongylidiellum edentatum, (c) Kratochviliella bicapitata, (d) Oreonetides quadridentatus (black males, white females, grey juveniles; $x$-axis: Roman numerals represent the months; $y$-axis: numbers of trapped specimens); a Clubiona leucaspis (no traps operated from November/XI to January/l), totals $441 \hat{\jmath} \widehat{\delta}, 159+q, 1231$ juv.; b Gongylidiellum edentatum, totals $12 \hat{\sigma} \hat{\sigma}, 45 q q$ (incl. $3 \hat{\sigma} \hat{\sigma}, 7 q \rho$ in long winter periods, i.e. Nov./Dec. to end of April/beginning of May - not included

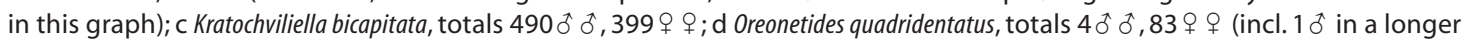
winter period, i.e. mid Nov. to mid of March - not included in this graph) 
specimens. Details: $29-55$ species (Ø $41.2 \pm 8.8), 580$ 3422 spiders (Ø $2017 \pm 918)$. FINCH (2001) caught from spring to autumn on 6 living trees ( 3 beeches, 2 oaks, 1 Scots pine - open type after FUNKE 1971) 110 species $(\varnothing 35.2 \pm 15.3)$, and 56 species on two lying dead trees.

All these data fit in the ranges given above for single trees. The eclector type without a bottle traps fewer specimens (and presumably less species) than the type with a bottle. Nevertheless, data from the bottle-less type fit within the range. A possible reason: the range of species and specimen numbers on older trees (with a larger diameter) compared to younger trees is larger than the range resulting from trap type. The data from different regions in this paper already show that it is difficult to compare the published data. The reasons are that different trapping periods, different tree ages and diameters and finally different types of eclectors were used. Nevertheless, important conclusions can be drawn (see also BLICK 2010):

- spiders are a species rich group on forests floors, as well as on trees;

- to estimate their biodiversity in forests data from both the forest floor and from trees are necessary;

- the majority of the dominant species do not prefer conifers or broad-leafed tress; instead they are widely distributed;

- in Germany forest spider species that are restricted in their distribution to Central Europe (s.l.) occur;

- the diversity and importance of the spider fauna on bark in Central Europe was until now underestimated compared with the epigeal fauna (even though there is an overlap of both coenoses).

\section{Acknowledgements}

My thanks go: to Andreas Malten (Frankfurt am Main), who determined the spiders of three strict forest reserves and to Ingmar Weiss (Grafenau-Rosenau), who determined a part of the spiders from Frankfurt; to the whole team of the Strict Forest Reserve Project, especially to Wolfgang Dorow (Frankfurt am Main), the old stager of the project; to Aloysius Staudt (Schmelz) for his great work on the German www-distribution maps; to Tim Taeger and Ulrich Schultz (Eberswalde) for their field and lab work; to Kerstin Engel, Martin Goßner (formerly Freising), and Andreas Malten for collecting the spiders and for arranging finances; last but not least to Andrew Liston (Müncheberg) for improving the English. Research on the Strict Forest Reserves in Hesse was conducted in cooperation with and financially supported by the 'Landesbetrieb Hessen-Forst'.

\section{References}

ALBERT R. (1982): Untersuchungen zur Struktur und Dynamik von Spinnengesellschaften verschiedener Vegetationstypen im Hoch-Solling. - Hochschul-Sammlung Naturwissenschaft Biologie 16: 1-147

BEHRE G. (1989): Freilandökologische Methoden zur Erfassung der Entomofauna (Weiter- und Neuentwicklung von Geräten). - Jahresberichte des Naturwissenschaftlichen Vereins in Wuppertal 42: 238-242

BLICK T. (2009): Die Spinnen (Araneae) des Naturwaldreservats Goldbachs- und Ziebachsrück (Hessen). Untersuchungszeitraum 1994-1996. - Mitteilungen der Hessischen Landesforstverwaltung 45: 57-138

BLICK T. (2010): Spider coenoses in Strict Forest Reserves in Hesse (Germany). - European Arachnology 2008. Proceedings of the 24th European Congress of Arachnology, Bern 2008: 11-29

Bosmans R., J.-P. Maelfait \& A. De Kimpe (1986): Analysis of the spider communities in an altitudinal gradient in the French and Spanish Pyrénées. - Bulletin of the British arachnological Society 7: 69-76

BRAUN D. (1992): Aspekte der Vertikalverteilung von Spinnen (Araneae) an Kiefernstämmen. - Arachnologische Mitteilungen 4: 1-20

CZAJKa M. \& S. BEDNARZ (1972): Biology of Pelecopsis bicapitata Miller, 1938 (Erigonidae). - Proceedings of the $5^{\text {th }}$ International Congress of Arachnology, Brno 1971: 85-87

Dorow W.H.O., G. Flechtner \& J.-P. Kopelke (1992): Naturwaldreservate in Hessen. Band 3. Zoologische Untersuchungen - Konzept. - Mitteilungen der Hessischen Landesforstverwaltung 26: 1-159

Dorow W.H.O., T. BLICK \& J.-P. KOPELKE (2009): Untersuchungsgebiet und Methoden. Naturwaldreservat Goldbachs- und Ziebachsrück (Hessen). Untersuchungszeitraum 1994-1996. - Mitteilungen der Hessischen Landesforstverwaltung 45: 7-24

Dorow W.H.O., T. BLICK \& J.-P. KOPELKE (2010): Zoologische Forschung in hessischen Naturwaldreservaten. Exemplarische Ergebnisse und Perspektiven. - Forstarchiv 81: 61-68 - doi: 10.2376/0300-4112-81-61

Dorow W.H.O., G. Flechtner \& J.-P. KopelKe (2004): Übersicht über die Tiergruppen und ihre Bedeutung für den Naturschutz. Naturwaldreservate in Hessen. Band 6/2.2 Schönbuche. Zoologische Untersuchungen 1990-1992, Teil 2. - Hessen-Forst - FIV Ergebnis- und Forschungsbericht 28/2: 319-326

ELLENBERG H., R. MAYER \& J. SCHAUERMANN (1986): Ökosystemforschung. Ergebnisse des Solling-Projekts 1966-1986. Ulmer, Stuttgart. 507 pp.

ENGEL K. (1999): Analyse und Bewertung von Umbaumaßnahmen in Fichtenreinbeständen anhand ökologischer Gilden der Wirbellosen-Fauna. Wissenschaft \& Technik, Berlin. 170 pp. \& Appendix 
ENGEL K. (2001): Vergleich der Webspinnen (Araneae) und Weberknechte (Opiliones) in 6 Buchen- und Fichtenbeständen Bayerns. - Arachnologische Mitteilungen 21: $14-31$

FINCH O.-D. (2001): Zönologische und parasitologische Untersuchungen an Spinnen (Arachnida, Araneae) niedersächsischer Waldstandorte. - Archiv zoologischer Publikationen 4: 1-199, A1-A35

FUNKE W. (1971): Food and energy turnover of leaf-eating insects and their influence on primary production. In: ELLENBERG H. (ed.): Integrated experimental ecology. Methods and results of ecosystem research in the German Solling Project. - Ecological Studies 2: 81-93

GoerTZ D. (1998) Zur Refugialfunktion von Auwaldrelikten in der Kulturlandschaft des Mittleren Saaletals. Spinnenassoziationen als Modellgruppe zur Habitatbewertung. Diploma thesis, Jena. 73 pp. \& Appendix

Gossner M. (2004): Diversität und Struktur arborikoler Arthropodenzönosen fremdländischer und einheimischer Baumarten. Ein Beitrag zur Bewertung des Anbaus von Douglasie (Pseudotsuga menziesii (Mirb.) Franco) und Roteiche (Quercus rubra L.). - Neobiota 5: 1-324

HÄNGGI A., E. STÖCKLI \&W. NENTWIG (1995): Lebensräume mitteleuropäischer Spinnen. Charakterisierung der Lebensräume der häufigsten Spinnenarten Mitteleuropas und der mit diesen vergesellschafteten Arten. - Miscellanea Faunistica Helvetiae 4: 1-459

JANTSCHER E. (2001): Revision der Krabbenspinnengattung Xysticus C.L. Koch, 1835 (Araneae, Thomisidae) in Zentraleuropa. Thesis, Graz. 328 pp. \& 81 tables

MALTEN A. (1994): Fünf für Deutschland neue Spinnenarten - Lepthyphantes midas, Neriene furtiva, Hahnia petrobia, Clubiona leucaspis, Diaea pictilis (Araneae: Linyphiidae, Hahniidae, Clubionidae, Thomisidae). - Arachnologische Mitteilungen 8: 58-62

MALTEN A. (1999): Araneae (Spinnen). Naturwaldreservate in Hessen, Band 5/2.1. Niddahänge östlich Rudingshain. Zoologische Untersuchungen 1990-1992, Teil 1. - Mitteilungen der Hessischen Landesforstverwaltung 32/1: 85-197

MALTEN A. (2001): Araneae (Spinnen). Naturwaldreservate in Hessen, Band 6/2.1. Schönbuche. Zoologische Untersuchungen. 1990-1992, Teil 1. - Hessen-Forst - FIV Ergebnis- und Forschungsbericht 28/1: 35-132

Malten A. \& T. Blick (2007): Araneae (Spinnen). Naturwaldreservate in Hessen, Band 7/2.2. Hohestein. Zoologische Untersuchungen 1994-1994, Teil 2. - Mitteilungen der Hessischen Landesforstverwaltung 42: 7-93
Malten A., D. Bönsel, M. Fehlow \& G. ZizKA (2003): Erfassung von Flora, Fauna und Biotoptypen im Umfeld des Flughafens Frankfurt am Main. Teil II. Untersuchungsgebiet Schwanheim. Frankfurt am Main, Forschungsinstitut Senckenberg, Arbeitsgruppe Biotopkartierung. 163 pp. - Internet: http://senckenberg. de/files/content/forschung/abteilung/botanik/phanerogamen1/pro2_2_s.pdf [accessed 28.XII.2009].

MiKHAILOV K.G. (1997): Catalogue of the spiders of the territories of the former Soviet Union (Arachnida, Aranei). Archives of the Zoological Museum of the Moscow State University, Moscow. 416 pp.

Muster C. (2009): Phylogenetic relationships within Philodromidae, with a taxonomic revision of Philodromus subgenus Artanes in the western Palearctic (Arachnida: Araneae). - Invertebrate Systematics 23: 135-169 - doi:10.1071/IS08044

NIELSEN B.O. (1974): Registrering af insektaktivitet på bøgestammer ved hjælp af fangtragte (A record of insect activity on beech stems (Fagus silvatica L.) by means of arboreal photoeclectors). - Entomologiske Meddelelser 42: $1-18$

Platen R. (1985): Die Spinnentierfauna (Araneae, Opiliones) aus Boden- und Baumeklektoren des Staatswaldes Burgholz (MB 4708). - Jahresberichte des Naturwissenschaftlichen Vereins in Wuppertal 38: 75-86

PLATNICK N.I. (2009): The world spider catalog, version 10.0. American Museum of Natural History. - Internet: http://research.amnh.org/iz/spiders/catalog_10.0 [accessed 15.XII.2009]

RÖDER J., C. BÄSSLER, R. BRANDl, L. DVOraK, A. FLOREN, M.M. GOSSNER, A. GRUPPE, A. JARZABEKMÜller, O. Vojtech, C. Wagner \& J. MÜller (2010): Arthropod species richness in the Norway Spruce (Picea abies (L.) Karst.) canopy along an elevation gradient. - Forest Ecology and Management 259: 15131521 - doi: 10.1016/j.foreco.2010.01.027

SIMON U. (1995): Untersuchung der Stratozönosen von Spinnen und Weberknechten (Arachn.: Araneae, Opilionida) an der Waldkiefer (Pinus sylvetris L.). Wissenschaft \& Technik, Berlin. 142 pp.

STAUDT A. (2009): Nachweiskarten der Spinnentiere Deutschlands (Arachnida: Araneae, Opiliones, Pseudoscorpiones). - Internet: http://spiderling.de/arages [accessed 28.XII.2009].

TofT S. (1976): Life-histories of spiders in a Danish beech wood. - Natura Jutlandica 19: 5-40

WunderLich J. (1982): Mitteleuropäische Spinnen (Araneae) der Baumrinde. - Zeitschrift für angewandte Entomologie 94: 9-21 - doi: 10.1111/j.1439-0418.1982. tb02540.x 